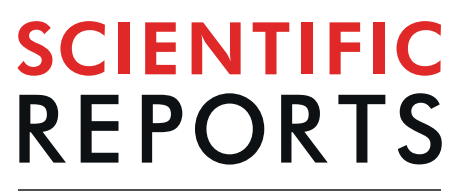

natureresearch

Check for updates

\title{
Life on a Mesoarchean marine shelf - insights from the world's oldest known granular iron formation
}

\author{
Albertus J. B. Smith ${ }^{1,2}$, Nicolas J. Beukes ${ }^{1,2}$, Jens Gutzmer ${ }^{1,2,3,4}$, Clark M. Johnson ${ }^{5}$, \\ Andrew D. Czaja ${ }^{5,6}$, Noah Nhleko ${ }^{1,7}$, Frikkie de Beer ${ }^{8,9}$, Jakobus W. Hoffman ${ }^{8}$ \& \\ Stanley M. Awramik ${ }^{10}$
}

The Nconga Formation of the Mesoarchean ( 2.96-2.84 Ga) Mozaan Group of the Pongola Supergroup of southern Africa contains the world's oldest known granular iron formation. Three dimensional reconstructions of the granules using micro-focus $X$-ray computed tomography reveal that these granules are microstromatolites coated by magnetite and calcite, and can therefore be classified as oncoids. The reconstructions also show damage to the granule coatings caused by sedimentary transport during formation of the granules and eventual deposition as density currents. The detailed, three dimensional morphology of the granules in conjunction with previously published geochemical and isotope data indicate a biogenic origin for iron precipitation around chert granules on the shallow shelf of one of the oldest supracratonic environments on Earth almost three billion years ago. It broadens our understanding of biologically-mediated iron precipitation during the Archean by illustrating that it took place on the shallow marine shelf coevally with deeper water, below-wave base iron precipitation in micritic iron formations.

Iron formation (IF, a chemical sedimentary rock containing at least $15 \mathrm{wt} \%$ iron $^{1,2}$ ) has been at the centre of debate with regards to early life on Earth ${ }^{3,4}$ with numerous authors having suggested bacterially mediated deposition of iron-rich mineral precursors ${ }^{5-11}$. Bacterially mediated oxidation of ferrous iron to ferric iron serves as a viable mechanism for iron oxidation in the oxygen-poor surface environments of the Earth prior to the approximately 2.45-2.32 Ga Great Oxidation Event $(\mathrm{GOE})^{12,13}$. It also serves to explain certain mineral and geochemical features of $\mathrm{IF}^{2,10,14}$. Granular iron formation (GIF) is a textural subtype of IF where chemically precipitated precursor sediment has been reworked and deposited as endoclastic sands ${ }^{2}$, and mostly occur between approximately 2.4 and $1.9 \mathrm{Ga}^{14}$. GIFs are particularly important to understand as they potentially record iron redox processes in the shallowest parts of the oceans, as compared to IFs in general, most of which were deposited in deep water. However, biological mediation of IF deposition is still debated due to a lack of direct (i.e. textural) evidence for biological activity in older $(>2 \mathrm{Ga}$ ) occurrences, with some authors even preferring abiological models for IF deposition $^{15,16}$. This contribution presents the first three-dimensional textural evidence, acquired using micro-focus $\mathrm{X}$-ray computed tomography $(\mu \mathrm{XCT})$, which provides strong evidence that biological activity played an important role in the deposition of IF. Our evidence comes from the exceptionally well preserved - and oldest known GIF of the Nconga Formation in the Mesoarchean Mozaan Group of the Pongola Supergroup of southern Africa.

The Mozaan Group of the Pongola Supergroup (Fig. 1) is one of the oldest supracratonic successions on Earth with a depositional age of approximately 2.96 to $2.84 \mathrm{Ga}^{17,18}$, and, together with the Witwatersrand Supergroup, comprise the oldest well-exposed marine basin known ${ }^{3,10}$. The Mozaan Group is also known to host microbial

\footnotetext{
${ }^{1}$ Paleoproterozoic Mineralization Research Group, Department of Geology, University of Johannesburg, Johannesburg, South Africa. ${ }^{2}$ Department of Science and Technology-National Research Foundation Centre of Excellence for Integrated Mineral and Energy Resource Analysis, University of Johannesburg, Johannesburg, South Africa. ${ }^{3}$ Helmholtz Zentrum Dresden-Rossendorf, Helmholtz Institute Freiberg for Resource Technology, Freiberg, Germany. ${ }^{4}$ Department of Mineralogy, TU Bergakademie Freiberg, Freiberg, Germany. ${ }^{5}$ Department of Geoscience, University of Wisconsin, Madison, WI, USA. ${ }^{6}$ Department of Geology, University of Cincinnati, Cincinnati, OH, USA. ${ }^{7}$ Geological Survey and Mines Department, Mbabane, Swaziland. ${ }^{8}$ Radiation Science, South African Nuclear Energy Corporation SOC Ltd. (Necsa), Pelindaba Industrial Site, Gauteng, South Africa. ${ }^{9}$ Senior Research Associate, Department of Anthropology \& Development Studies, University of Johannesburg, Johannesburg, South Africa. ${ }^{10}$ Department of Earth Sciences, University of California, Santa Barbara, CA, USA. ${ }^{\circledR e}$-mail: bertuss@uj.ac.za
} 


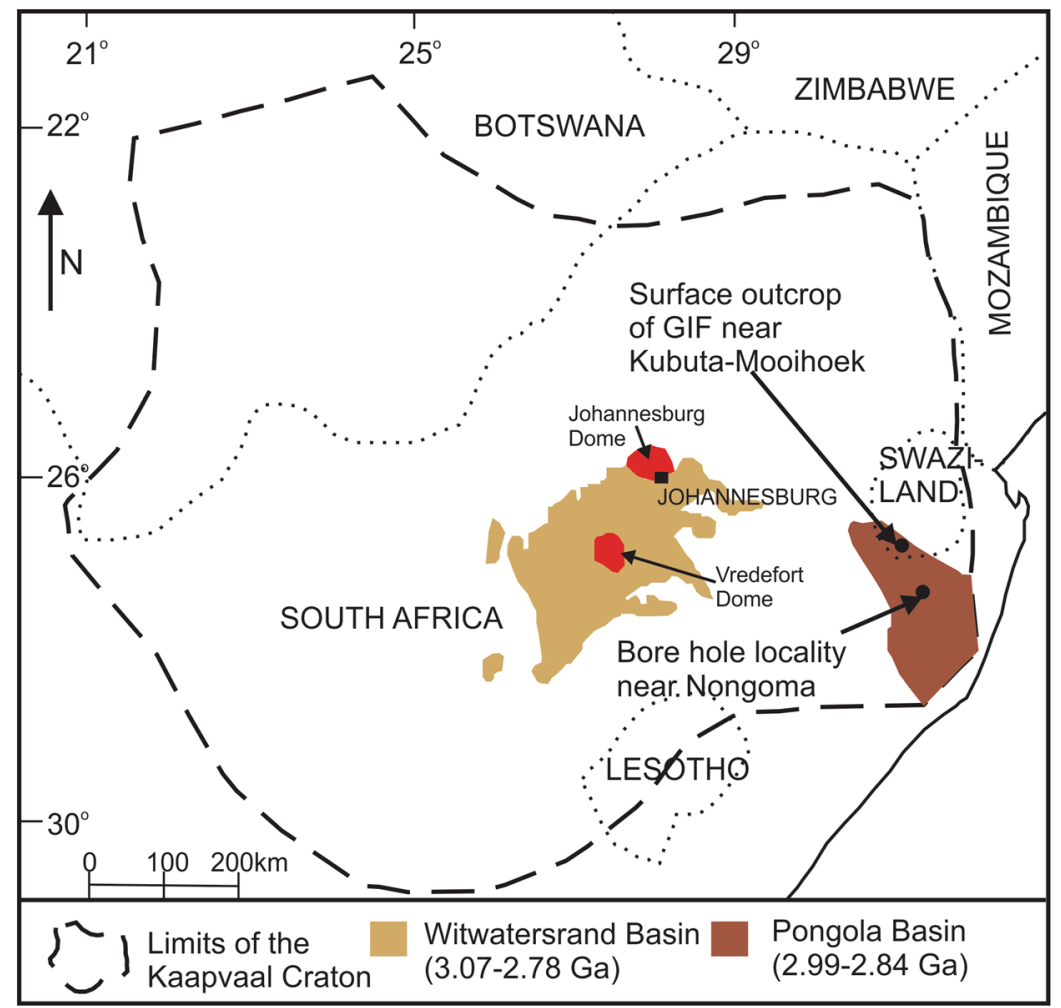

Figure 1. Location of the Pongola Supergroup as well as the studied outcrop and drill core localities on the Kaapvaal Craton of southern Africa. The figure is adapted from ${ }^{25}$. The figure was created using CorelDRAW 2017(www.coreldraw.com).

mat structures in some of its sandstone units ${ }^{19}$. The Mozaan Group contains ten iron-rich sedimentary beds ${ }^{3}$, of which the basal IF in the Vlakhoek Member has been the subject of several recent studies about pre-GOE oxygen oases $^{20-24}$. Less studied, however, is the Nconga Formation, which occurs towards the top of the Mozaan Group. The Nconga Formation contains an iron-rich unit that includes banded IF, massive IF and, importantly, stacked interbeds of GIF; this is the oldest known occurrence of GIF $^{25}$. The granules in the GIF are 0.5 to $3 \mathrm{~mm}$ in diameter (Supplementary Figs. 1A and B) and comprise microcrystalline quartz (chert) with minor calcite cores surrounded by magnetite and calcite rims and hosted by a matrix of chert (Supplementary Fig. 1C and D) and minor minnesotaite ${ }^{25}$. The GIF beds are upward fining and capped by iron-rich mudstone (Supplementary Fig. 1A and $\mathrm{E}$; Supplementary Video 1 and 2). Calcite shows depleted $\delta^{13} \mathrm{C}_{\mathrm{PDB}}$ values $\left(-15.7\right.$ to $-11.6^{0} \%$, suggestive of diagenetic calcite formation from organic carbon oxidation, and the magnetite is marked by heavy $\delta^{56} \mathrm{Fe}$ values $(0.39$ to $0.45 \%$ ), indicating partial oxidation of aqueous $\mathrm{Fe}^{2+}$ as the main mechanism of iron precipitation ${ }^{25}$. The only iron oxide present in the drill core samples is magnetite, whereas surface samples have been oxidized to hematite $^{25}$. The drill core and outcrop samples show minimal deformation, no evidence of hydrothermal overprint and the metamorphic grade was no higher than lower greenschist facies ${ }^{25}$.

The granule rims are irregular, with multiple magnetite interlayers appearing to mark microdomal structures (Supplementary Fig. 1B-D). The complex structure of the granule rims in the Nconga Formation GIF makes thin section petrography by optical and scanning electron microscope difficult due to the unavoidable bias introduced by two dimensional assessments of three dimensional features (Supplementary Video 3 and 4). The large difference in density between the magnetite in the granule rims and the quartz in the granule cores and matrix, however, presented a unique opportunity to conduct $\mu$ XCT studies on the Nconga Formation GIF in order to reveal external morphology and textural details.

\section{Results and granule morphology}

The results focus on the false colour $3 \mathrm{D} \mu \mathrm{XCT}$ reconstructions of four granules, hereafter referred to as granules A, B, C and D (Fig. 2; Supplementary Videos 5 to 11) from two drill core samples. Supplementary Figures $1 \mathrm{~A}$ and $\mathrm{B}$ are representations of the true colour of the studied samples and the granules, which have black magnetite rims. Granules A and B come from one sample (Fig. 2A and B) and granules C and D from the other sample (Fig. 2C and D). It is important to note that the granules have been imaged in false colour, with denser minerals brighter grey than less dense minerals. So although the outer coating, which comprises magnetite, has been imaged bright grey, the true coating colour is black to dark grey. The granules have the shape of tri-axial ellipsoids, with the three perpendicular axes having different lengths. The granules appear to show no preferred orientation, with the longest axes oriented either vertically (Fig. 2A) or close to horizontally (Fig. 2B to D) with respect to the bedding surfaces. All studied granules have approximately similar sizes and exterior appearances. 

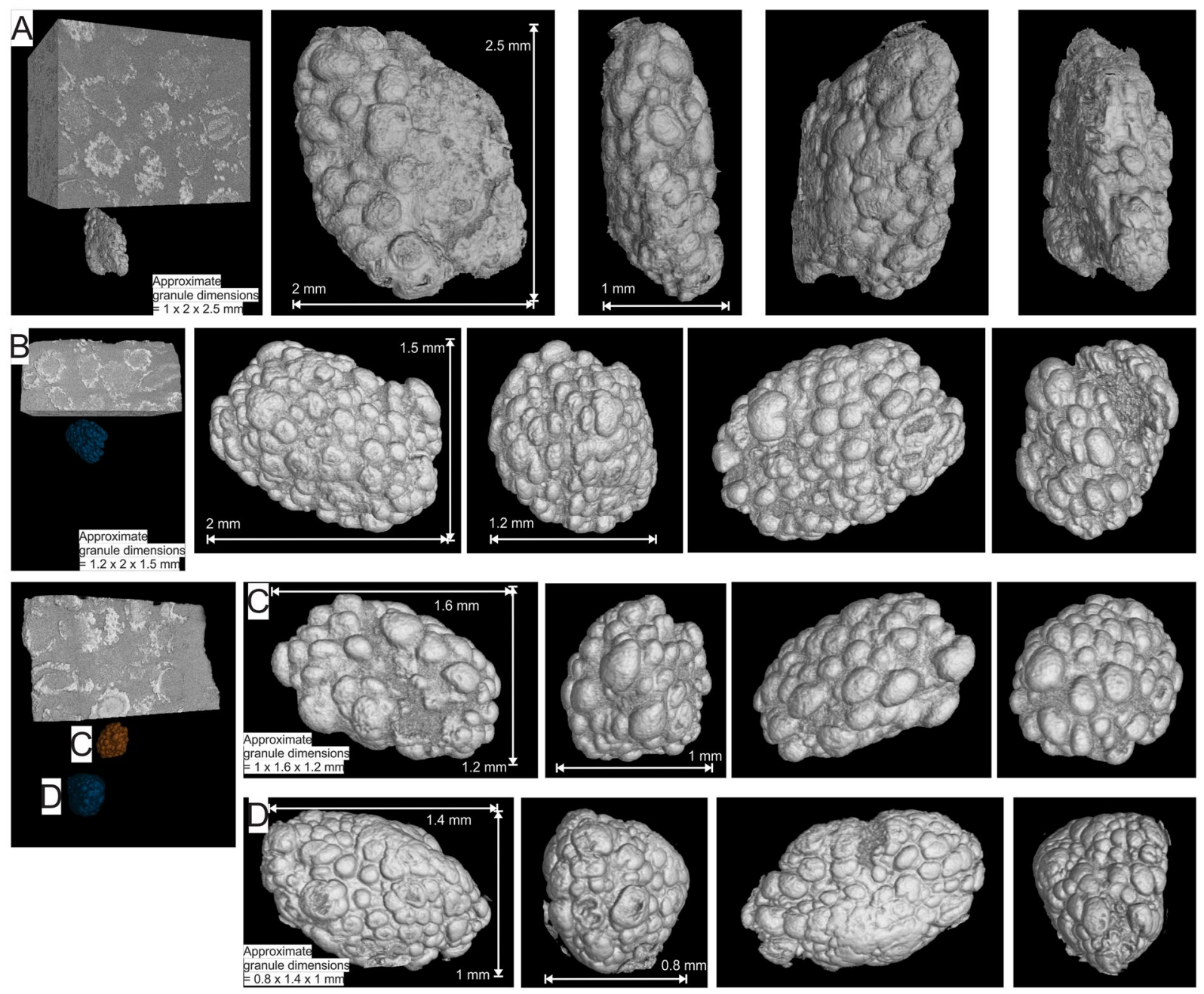

Figure 2. False colour three dimensional reconstructions of $\mu \mathrm{XCT}$ scans of four magnetite coated granules (A to D) from drill core samples of the Nconga Formation GIF, illustrating, from left to right, the location and orientation of the granules in the sample blocks, and an anti-clockwise rotation (when viewed from top) through each grain. See the following supplementary videos for full rotational animations of the core samples and extracted granules: 5 and 6 for granule A; 7 and 8 for granule B; 9 and 10 for granule C; 9 and 11 for granule D. The images were created using VGStudio Max version 3.2 (https://www.volumegraphics.com/en/products/ vgstudio-max.html) and the final figure was compiled using CorelDRAW 2017 (www.coreldraw.com).

The most prominent feature observed in the $3 \mathrm{D} \mu \mathrm{XCT}$ reconstructions, are the multiple domical structures surrounding, or coating, the outer surface of all the Nconga Formation GIF granules, giving them a knobby appearance (Fig. 3; Supplementary Videos 6, 8, 10 and 11). The structures have an outer coating of magnetite with inner laminae comprising calcite and magnetite ${ }^{25}$ (Supplementary Fig. 1). In plan view, the majority of these granule surface structures are circular with a subordinate amount being ellipsoidal (e.g. Fig. 3A and C), with diameters ranging from approximately 30 to $400 \mu \mathrm{m}$ and with the majority falling in the range of approximately 100 to 300 $\mu \mathrm{m}$. Although some of the surface structures show partial coalescence (e.g. Fig. 3B), they are mostly separate and occur directly on the outer granule surface and not on top of each other.

The $3 \mathrm{D} \mu \mathrm{XCT}$ reconstructions also show modifications to the outer surface of the granules and the domical structures (Fig. 4; Supplementary Videos 6, 8, 10 and 11). These modifications take three main forms, namely: i) scouring and smoothing of the outer coating, expressed as the absence (Fig. 4A) or partial smoothing (Fig. 4D) of the domical surface structures; ii) prominent breaks in or the removal of the outer magnetite coating (Fig. 4B1 and D); and iii) damage to the domical surface structures (Fig. 4A,B2 and C).

The majority of the granules are composed of chert and minor calcite cores with rims of interlaminated magnetite and calcite ${ }^{25}$ (Supplementary Fig. 1C and E; Fig. 5A and B; Supplementary Video 6). Few of the granules have a more complex internal structure. The granules contain magnetite-rich nuclei, coated by chert which, in turn, is coated by the same magnetite and calcite domical surface structures as observed in all the other granules (Fig. 5D; Supplementary Video 12). 

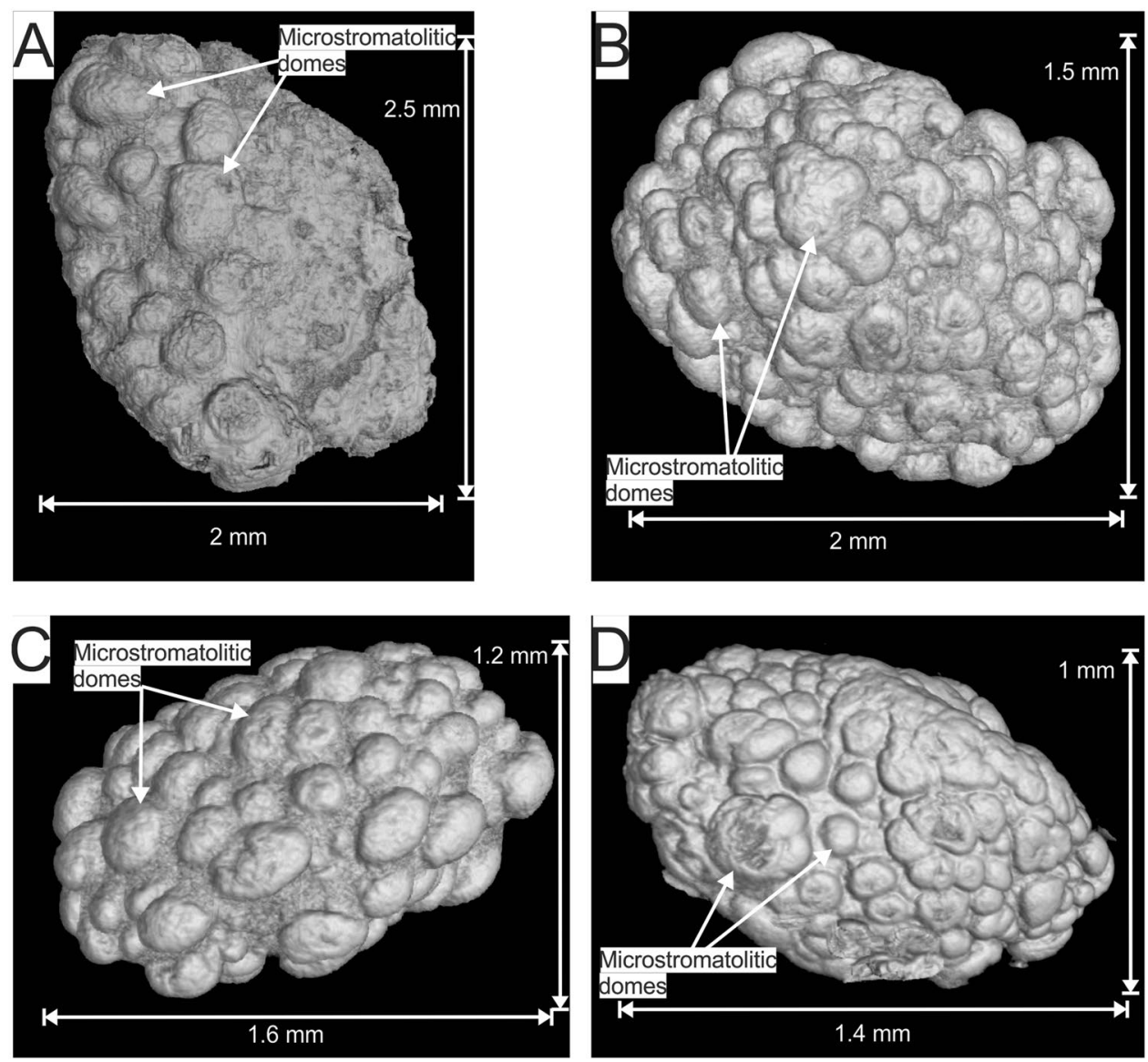

Figure 3. False colour three dimensional reconstructions of $\mu \mathrm{XCT}$ scans of the same four magnetite coated granules from Fig. 2 from drill core samples of the Nconga Formation GIF illustrating the multiple domical structures surrounding, or coating, the outer surface of all the granules. See the following supplementary videos for full rotational animations of the extracted granules: 6 for granule A; 8 for granule B; 10 for granule C; 11 for granule D. The images were created using VGStudio Max version 3.2 (https://www.volumegraphics.com/en/ products/vgstudio-max.html) and the final figure was compiled in CorelDRAW 2017 (www.coreldraw.com).

\section{Discussion}

From the 3D $\mu \mathrm{XCT}$ reconstructions of the individual granules in the Nconga Formation GIF (Fig. 3), it can be seen that the surface structures resemble domical microstromatolites ${ }^{26}$. The overall morphology of the granules can therefore be classified as oncoidal, i.e., stromatolites that occur around grains ${ }^{27}$. In conjunction with the previously published highly negative carbonate $\delta^{13} \mathrm{C}_{\mathrm{PDB}}$ values $(-15.7$ to $-11.6 \%$ o $)$, suggestive of organic carbon input, and the heavy magnetite $\delta^{56} \mathrm{Fe}$ values $(0.39$ to $0.45 \%$ \% $)$, indicative of partial oxidation of aqueous $\mathrm{Fe}^{2+}$, the observed oncoids were most likely formed by iron-oxidizing bacteria populating the exterior surface of chert granules in a shallow water, occasionally wave-agitated depositional environment ${ }^{25}$. The environmental interpretation is supported by sedimentary structures such as cross bedding and ripples observed in the outcrop in the Kubuta-Mooihoek area of Swaziland ${ }^{25}$. The iron-oxidizing bacteria could have been anoxygenic photoferrotrophs $s^{5,6}$, as the granules were formed above wave base and, therefore, in the photic zone. However, chemolithoautotrophs, that function under low concentrations of free oxygen ${ }^{5}$, cannot be eliminated as a possibility due to the strong evidence of an oxygen oasis in the Mozaan depositional basin ${ }^{21-23}$ as well as the possible influence of nitrate as an organic carbon oxidant, as suggested by the lack of Fe-bearing carbonates in the rock ${ }^{25}$.

The granule morphology is also not typical of other GIF occurrences around the world, where the granule rims appear smooth and rounded ${ }^{28-30}$. Microbialite knobby surfaces are known from younger, larger oncoids ${ }^{31}$ (Supplementary Fig. 2), microbial mats ${ }^{32}$ and as bumpy surfaces on columnar stromatolites ${ }^{33}$. More recently formed (Phanerozoic) shallow marine ferromanganese oncoids, which have been linked to microbial mediation in their formation, also show similar-looking external knobby surfaces ${ }^{34,35}$. There are also some depositional setting similarities between these Phanerozoic ferromanganese oncoids and the Nconga GIF granules, sharing a shallow marine setting above or close to wave base ${ }^{25,34,35}$. However, the more recent ferromanganese oncoids are different from the Nconga GIF granules in that the ferromanganese oncoids are different in size, either being orders of magnitude larger ${ }^{34}$ or smaller ${ }^{35}$ than the Nconga GIF granules. Additionally, the ferromanganese oncoids typically have concentric internal structures ${ }^{34,35}$ and can also have high clastic inputs ${ }^{35}$, which are both absent in the Nconga GIF granules ${ }^{25}$. 

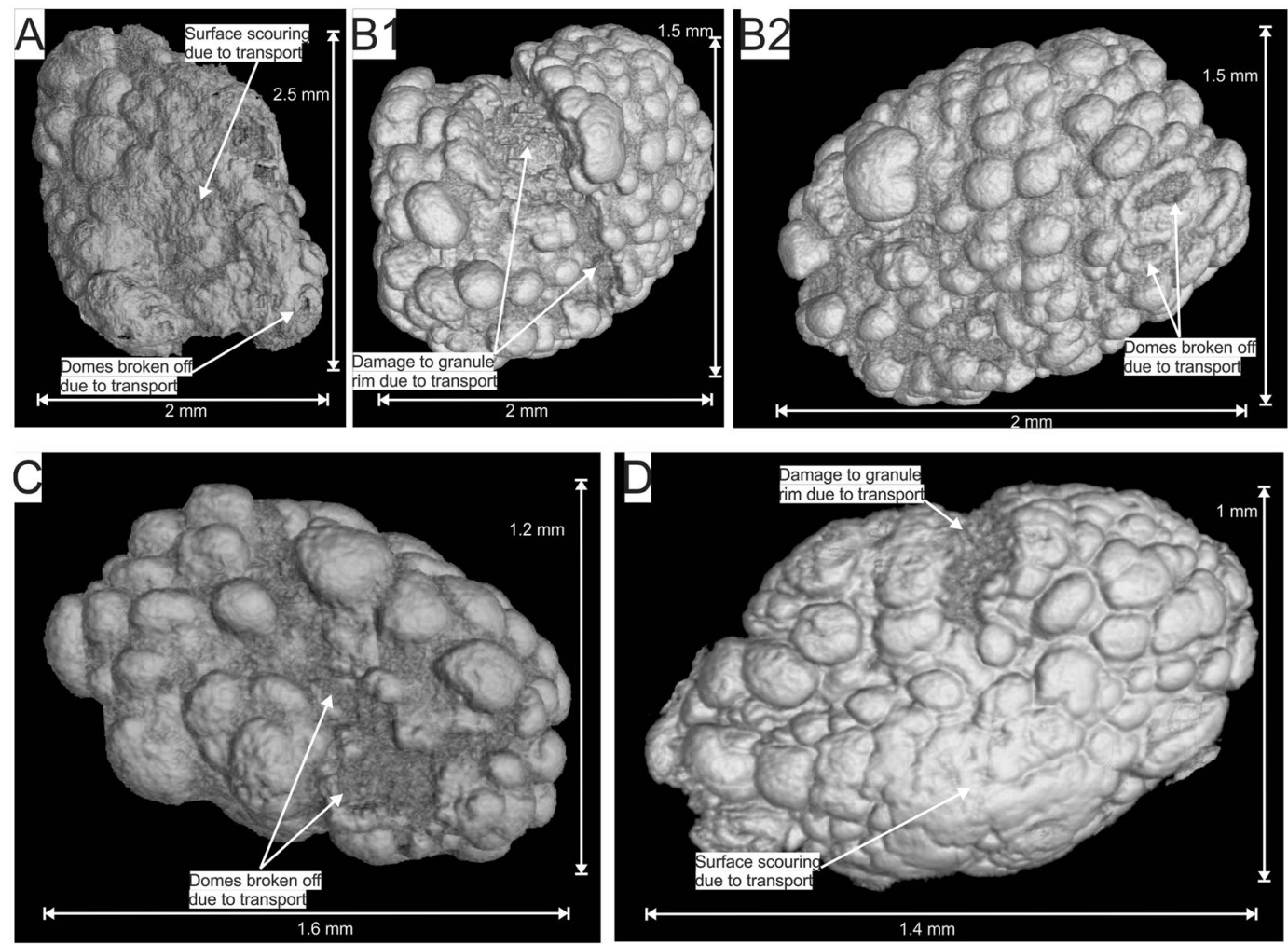

Figure 4. False colour three dimensional reconstructions of $\mu \mathrm{XCT}$ scans of the same four magnetite coated granules granules from Fig. 2 from drill core samples of the Nconga Formation GIF illustrating different alterations to the outer surface of the granules and the domical structures (see text for more detail). See the following supplementary videos for full rotational animations of the extracted granules: 6 for granule A; 8 for granule B; 10 for granule C; 11 for granule D. The images were created using VGStudio Max version 3.2 (https://www.volumegraphics.com/en/products/vgstudio-max.html) and the final figure was compiled using CorelDRAW 2017 (www.coreldraw.com).

An alternative interpretation for the morphology of the granules could be that they are hydrothermal siliceous botryoidal sinters, also termed geyserites ${ }^{36-38}$, and therefore potentially do not mark biological structures ${ }^{38}$. There are, however, numerous differences between the Nconga GIF oncoids and botryoidal siliceous sinters that make this interpretation unlikely. Firstly, botryoidal siliceous sinters show a different morphology to that of the Nconga GIF oncoids, where the former comprise agglomerated microspheres, typically forming the whole granule and not only the surface coating ${ }^{37,38}$, and the latter show individual domical microstructures with limited coalescence occurring as a granule coating (Fig. 3). Secondly, the botryoidal siliceous sinters are entirely composed of silica ${ }^{37,38}$, whereas the Ngona GIF granules contain significant magnetite and calcite that mostly occur as the granule coatings. Thirdly, hydrothermal sinters have marked differences in their geochemical composition when compared to the Nconga GIF. For example, hydrothermal sinters tend to have enriched trace metal (e.g. mean $\mathrm{Cu}$ contents of $\sim 20-160 \mathrm{ppm}$ ) and alkali earth metal contents (mean $\mathrm{K}_{2} \mathrm{O}$ and $\mathrm{Na}_{2} \mathrm{O}$ contents of $\sim 0.10-0.45$ and $\sim 0.12-1.14$ wt\% respectively) with low $\mathrm{Fe}_{2} \mathrm{O}_{3}$ contents ${ }^{38}$ (mean $\mathrm{Fe}_{2} \mathrm{O}_{3}$ contents of $\sim 0.16-6.51$ wt $\%$ ). The Nconga GIF, in contrast, generally have lower trace (e.g. $\mathrm{Cu}$ contents of 1.5 and $2.5 \mathrm{ppm})$ and alkali metal $\left(\mathrm{K}_{2} \mathrm{O}\right.$ and $\mathrm{Na}_{2} \mathrm{O}$ contents of $0.02-0.03 \mathrm{wt} \%$ and below detection limits respectively) contents and higher $\mathrm{Fe}_{2} \mathrm{O}_{3}$ contents $^{25}$ (17.26 and $24.03 \mathrm{wt} \%)$.

The 3D $\mu \mathrm{XCT}$ reconstructions of the individual granules also provide unique insight into their sedimentary history. The surface modification of the granule coatings in the form of scouring (Fig. 4A), smoothing (Fig. 4D), rim removal (Fig. 4B1 and D), and microstromatolite damage (Fig. 4B2 and C) illustrate that the granules experienced significant transport after their formation. In addition, the granules occur in upward-fining stacked beds ending in iron-rich mudstone (Supplementary Fig. 1A and E) stratigraphically juxtaposed next to deeper-water iron formations ${ }^{25}$, show multiple orientations (Fig. 2) and are chert matrix-supported (Supplementary Fig. 1A,B and E; Fig. 3). These characteristics all indicate the GIF beds were deposited as small, high-density turbidity flows, likely washed in from an original shallower water setting.

The internal 3D structure of the granules revealed that a minority of granules comprise magnetite-rich nuclei, coated by chert which, in turn, is coated by the same magnetite and calcite domical surface structures observed on all the granules (Fig. 5D). These granules have a more complex, polystadial formational history than the more common granules with chert nuclei (Fig. 5B). A possible interpretation is that a combination of chemical precipitation and sedimentary reworking has formed a composite granule, where an already existing oncoidal granule has been recoated by chert under wave agitation, with another generation of oncoidal laminae growing on the 

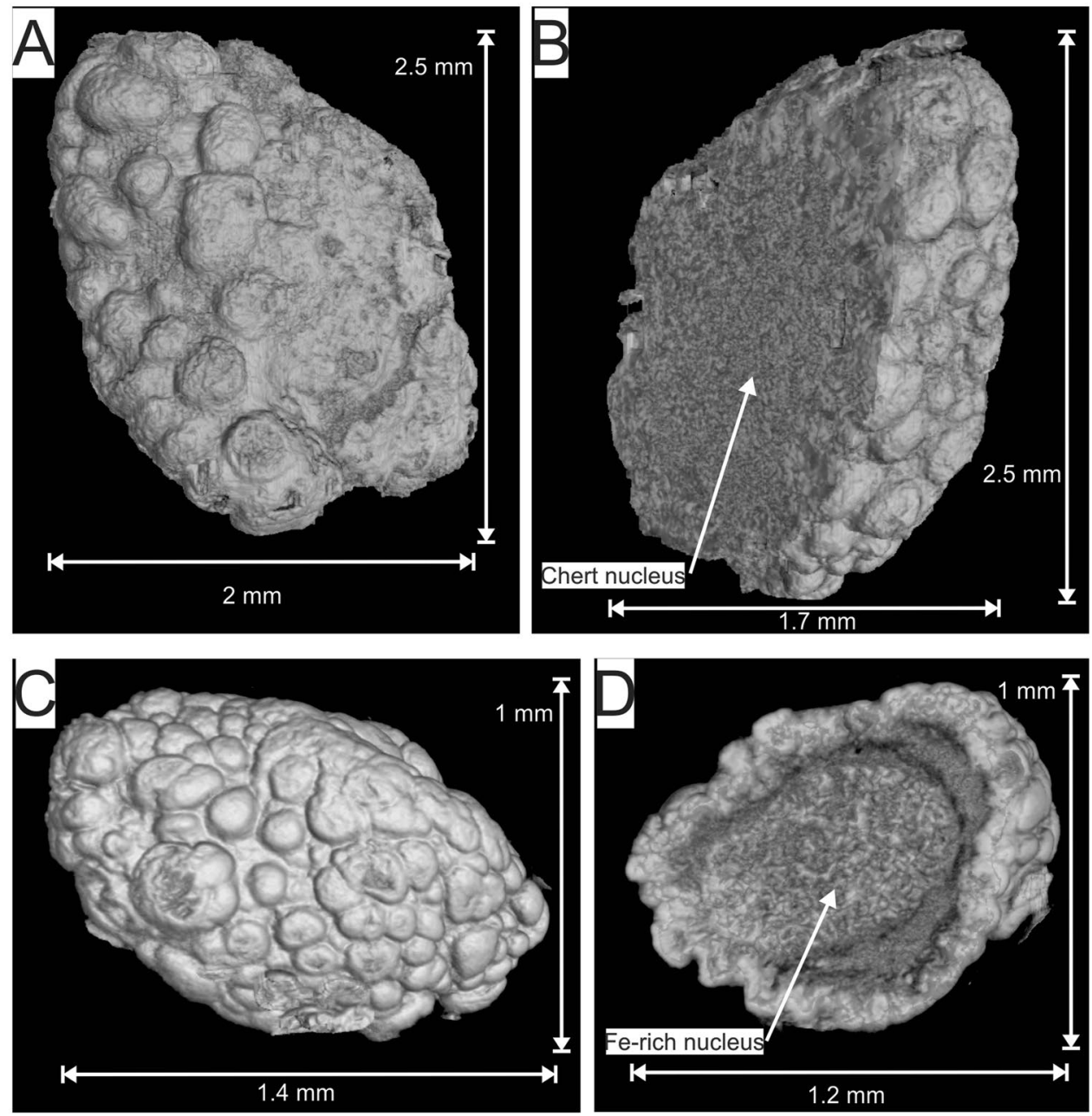

Figure 5. False colour three dimensional reconstruction and cross-sectional cutaway of the $\mu$ XCT scan of granule A (A and B) and D (C and D; Figs. 3-5) from the Nconga Formation GIF illustrating a the more common chert nucleus ${ }^{25}(\mathbf{B})$; and the less common magnetite-rich nucleus (D), the latter coated by chert which, in turn, is coated by magnetite and calcite domical surface structures. See the following supplementary videos for full rotational and cutaway animations of the extracted granules: 6 for A and B; 12 for C and D. The images were created using VGStudio Max version 3.2 (https://www.volumegraphics.com/en/products/vgstudio-max. html) and the final figure was compiled using CorelDRAW 2017 (www.coreldraw.com).

second generation external chert surface. Why only a minority of the granules has this more complex internal structure is not clear. One possibility is that due to density differences between the composite granules (denser due to higher magnetite contents) and the chert nucleus granules, sedimentary sorting mechanisms during transport concentrated the composite granules in a place either removed by erosion at a later stage or not intersected by the drill core.

\section{Conclusion}

This study is the first to document successful 3D $\mu$ XCT reconstructions of Archean microscale biological and sedimentary structures. In conjunction with the previously published stratigraphy, mineralogy and geochemistry of the Nconga Formation GIF, the 3D morphology of the granules suggest a mixed biological, chemical and sedimentary origin for this unique unit. It is also, at approximately $3 \mathrm{Ga}$, the oldest documented example of linking iron oxidation and precipitation to the formation of stromatolitic (oncoidal) structures in a demonstrably shallow-water environment. The results broaden our understanding of the environments for biologically mediated iron precipitation in the Archean, which included shallower marine shelf environments where bacterial iron precipitation could take place around granules in a wave-agitated water column. This happened coevally with the more commonly observed deeper water, below-wave base iron precipitation preserved in micritic IF.

\section{Methods}

For this study, three samples, one from outcrop from the Kubuta-Mooihoek area of Swaziland (Supplementary Fig. 1E) and two from an exploration drill core (Figs. 2-5) drilled 20-25 km north northeast of Nongoma in the KwaZulu-Natal Province of South Africa ${ }^{25}$, were selected and cut into blocks for $\mu$ XCT. The surface sample was cut into an approximately $30 \times 30 \times 55 \mathrm{~mm}$ block, whereas the drill core samples were cut into approximately 
$7 \times 7 \times 9 \mathrm{~mm}$ blocks. The reason for the latter blocks being smaller was that they could be placed closer to the $\mathrm{X}$-Ray source in order to obtain, through geometric enlargement, higher spatial resolution imaging of individual granules.

$\mu \mathrm{XCT}$ is a well-established analytical and visualization technique that has been applied within the geosciences that enables 3D information to be extracted in a non-destructive manner ${ }^{39}$. X-ray photoelectric absorption and Compton scattering are the most important principles in which X-rays are attenuated by material and are linked to material density in a linear relationship ${ }^{40}$. All the scans were conducted using an industrial Nikon XTH 225 ST $\mu X C T$ machine located at the South African Nuclear and Energy Corporation (Necsa) at Pelindaba, Northwest Province, South Africa. The Nikon XTH 225 ST $\mu$ XCT machine was fitted with a Perkin Elmer 1620 amorphous silicon detector as well as a $0.25 \mathrm{~mm}$ aluminium filter. The scans were conducted at $100 \mathrm{kV}$ (except for a surface sample that was done at $140 \mathrm{kV}$ ) and $100 \mathrm{~mA}$ with a scan frame rate of two frames per second. Scan time was 33 minutes and there were 1000 projections per sample. Reconstruction into a 3D virtual sample was performed using Nikon CTPro 3D reconstruction software ${ }^{41}$ while analysis was conducted in VGStudio Max3.2 analytical software ${ }^{42}$. Scanning potential and current parameters for this study were $100 \mathrm{kV}$ and $100 \mu \mathrm{A}$ respectively, which are based on the contrast observed in the X-ray projection images with a spatial resolution of $6.55 \mu \mathrm{m}$.

\section{Data availability}

All applicable data is in the manuscript and supplementary files. The original raw 3D $\mu$ XCT scan data $(\sim 50 \mathrm{~Gb})$ can be made available by the corresponding author upon request via a data depository.

Received: 10 April 2020; Accepted: 27 May 2020;

Published online: 29 June 2020

\section{References}

1. Klein, C. Some Precambrian banded iron-formations (BIFs) from around the world: Their age, geologic setting, mineralogy, metamorphism, geochemistry, and origin. Am. Min. 90, 1473-1499 (2005).

2. Beukes, N. J. \& Gutzmer, J. Origin and paleoenvironmental significance of major iron formations at the Archean-Paleoproterozoic boundary. Rev. Econ. Geol. 15, 5-47 (2008).

3. Smith, A. J. B. The Iron Formations of Southern Africa. In Siegesmund, S., Basei, M. A. S., Oyhantçabal, P. \& Oriolo, S. (eds.), Geology of Southwest Gondwana, Springer, Cham, 469-491 (2018).

4. Smith, A. J. B. The life and times of banded iron formations. Geology 43, 1111-1112 (2015).

5. Konhauser, K. O. et al. Could bacteria have formed the Precambrian banded iron formations? Geology 30, 1079-1082 (2002).

6. Kappler, A., Pasquero, C., Konhauser, K. O. \& Newman, D. K. Deposition of banded iron formations by anoxygenic phototrophic $\mathrm{Fe}(\mathrm{II})$-oxidizing bacteria. Geology 33, 865-868 (2005).

7. Dauphas, N., Cates, N. L., Mojzsis, S. J. \& Busigny, V. Identification of chemical sedimentary protoliths using iron isotopes in the> $3750 \mathrm{Ma}$ Nuvvuagittuq supracrustal belt, Canada. EPSL 254, 358-376 (2007).

8. Posth, N. R., Hegler, F., Konhauser, K. O. \& Kappler, A. Alternating Si and Fe deposition caused by temperature fluctuations in Precambrian oceans. Nat. Geosci. 1, 703-708 (2008).

9. Czaja, A. D. et al. Biological Fe oxidation controlled deposition of banded iron formation in the ca. 3770 Ma Isua Supracrustal Belt (West Greenland). EPSL 363, 192-203 (2013).

10. Smith, A. J. B., Beukes, N. J. \& Gutzmer, J. The composition and depositional environments of Mesoarchean iron formations of the West Rand Group of the Witwatersrand Supergroup, South Africa. Econ. Geol. 108, 111-134 (2013).

11. Konhauser, K. O. et al. Iron formations: A global record of Neoarchaean to Palaeoproterozoic environmental history. Earth-Sci. Rev. 172, 140-177 (2017).

12. Bekker, A. et al. Dating the rise of atmospheric oxygen. Nature 427, 117-120 (2004).

13. Holland, H. D. Sedimentary mineral deposits and the evolution of Earth's nearsurface environments. Econ. Geol. 100, 1489-1509 (2005).

14. Bekker, A. et al. Iron formation: The sedimentary product of a complex interplay among mantle, tectonic, oceanic, and biospheric processes. Econ. Geol. 105, 467-508 (2010).

15. Rasmussen, B., Krapež, B. \& Meier, D. B. Replacement origin for hematite in 2.5 Ga banded iron formation: Evidence for postdepositional oxidation of iron-bearing minerals. Geol. Soc. Am. Bull. 126, 438-446 (2014).

16. Rasmussen, B., Krapež, B., Muhling, J. R. \& Suvorova, A. Precipitation of iron silicate nanoparticles in early Precambrian oceans marks Earth's first iron age. Geology 43, 303-306 (2015).

17. Hegner, E., Kröner, A. \& Hunt, P. A precise U-Pb zircon age for the Archean Pongola Supergroup volcanics in Swaziland. J. Afr. Earth Sci. 18, 139-141 (1994).

18. Gutzmer, J., Beukes, N. J., Pickard, N. J. \& Barley, M. E. SHRIMP age of a quartz porphyry sill in the Mozaan group: Geochronological implication for the Pongola and the Witwatersrand Supergroups. S. Afr. J. Geol. 102, 139-146 (1999).

19. Noffke, N., Hazen, R. \& Nhleko, N. Earth's earliest microbial mats in a siliciclastic marine environment (2.9 Ga Mozaan Group, South Africa). Geology 31, 673-676 (2003).

20. Crowe, S. A. Atmospheric oxygenation three billion years ago. Nature 501, 535-538 (2013).

21. Planavsky, N. J. et al. Evidence for oxygenic photosynthesis half a billion years before the great oxidation event. Nat. Geosci. 7, 283-286 (2014)

22. Ossa Ossa, F. et al. Unusual manganese enrichment in the Mesoarchean Mozaan Group, Pongola Supergroup, South Africa. Precambrian Res. 281, 414-433 (2016).

23. Albut, G. et al. Modern rather than Mesoarchaean oxidative weathering responsible for the heavy stable Cr isotopic signatures of the 2.95 Ga old Ijzermijn iron formation (South Africa). Geochim. Cosmochim. Acta 228, 157-189 (2018).

24. Albut, G. et al. Modern weathering in outcrop samples versus ancient paleoredox information in drill core samples from a Mesoarchaean marine oxygen oasis in Pongola Supergroup, South Africa. Geochim. Cosmochim. Acta 265, 330-353 (2019).

25. Smith, A. J. B. et al. Oncoidal granular iron formation in the Mesoarchaean Pongola Supergroup, southern Africa: Textural and geochemical evidence for biological activity during iron deposition. Geobiology 15, 731-749 (2017).

26. Hofmann, H. J. Stromatolites from the Proterozoic Animikie and Sibley Groups, Ontario. Geol. Surv. Can., Pap. 68-69, 77p (1969).

27. Grey, K. \& Awramik, S. M. Handbook for the study and description of microbialites. GSWA Bull. 147, 279p (2020).

28. Dimroth, E. \& Chauvel, J.-J. Petrography of the Sokoman Iron Formation in Part of the Central Labrador Trough, Quebec, Canada. Geol. Soc. Am. Bull. 84, 111-134 (1973).

29. Simonson, B. M. \& Goode, A. D. T. First discovery of ferruginous chert arenites in the early Precambrian Hamersley Group of Western Australia. Geology 17, 269-272 (1989). 
30. Simonson, B. M. Origin and evolution of large Precambrian iron formations. In: Chan, M. A. \& Archer, A. W. (eds), Extreme depositional environments: Mega end members in geologic time, Geological Society of America Special Paper 370, Boulder, Colorado, 231-244 (2003).

31. Awramik, S. M., Buchheim, H. P., Leggit, L. \& Woo, K. S. Oncoids of the Late Pleistocene Manix Formation. San Bernardino County Museum Ass. Quart. 44, 25-31 (2000).

32. Bose, S. \& Chafetz, H. S. Topographic control on distribution of modern microbially induced sedimentary structures (MISS): a case study from Texas coast. Sed. Geol. 213, 136-149 (2009).

33. Grey, K. \& Blake, D. H. Neoproterozoic (Cryogenian) stromatolites from the Wolfe Basin, east Kimberley, Western Australia: correlation with the Centralian Superbasin. Aust. J. Earth Sci. 46, 329-341 (1999).

34. Reolid, M. \& Nieto, L. M. Jurassic Fe-Mn macro-oncoids from pelagic swells of the External Subbetic (Spain): evidences of microbial origin. Geologica Acta, 8, 151-168.

35. Giresse, P., Wiewióra, A. \& Lacka, B. Processes of Holocene ferromanganese-coated grains (oncolites) in the nearshore shelf of Cameroon. J. Sediment. Res. 68, 20-36 (1998).

36. Grellet-Tinner, G. \& Fiorelli, L. E. A new Argentinean nesting site showing neosauropod dinosaur reproduction in a Cretaceous hydrothermal environment. Nat. Commun. 1, 32, https://doi.org/10.1038/ncomms1031 (2010).

37. Campbell, K. A. et al. Geyserite in hot-spring siliceous sinter: Window on Earth's hottest terrestrial (paleo)environment and its extreme life. Earth-Sci. Rev. 148, 44-64 (2015).

38. Sanchez-Yanez, C., Reich, M., Leisen, M., Morata, D. \& Barra, F. Geochemistry of metals and metalloids in siliceous sinter deposits: Implications for elemental partitioning into silica phases. App. Geochem. 80, 112-133 (2017).

39. Godel, B., Barnes, S. \& Maier, W. D. 3-D Distribution of Sulphide Minerals in the Merensky Reef (Bushveld Complex, South Africa) and the J-M Reef (Stillwater Complex, USA) and their Relationship to Microstructures Using X-Ray Computed Tomography. Journal of Petrology 47(9), 1853-1872 (2006).

40. Van Geet, M., Swennen, R. \& David, P. Quantitative coal characterisation by means of microfocus X-ray computer tomography, colour image analysis and back-scattered scanning electron microscopy. International Journal of Coal Geology 46(1), 11-25 (2001).

41. Hoffman, J. W. \& De Beer, F. C. Characteristics of the Micro-focus X-ray Tomography Facility (MIXRAD) at Necsa in South Africa. 18th World Conference on Non-destructive Testing. 16-20 April 2012. Durban, South Africa. http://www.ndt.net/article/ wcndt2012/papers/37_wcndtfinal00037.pdf (2012).

42. Volume Graphics GmbH. VGStudio Max 2.2. 2014. http://www.volumegraphics.com/products/vgstudio/index.html

\section{Acknowledgements}

The authors wish to thank the Department of Geology at the University of Johannesburg, the Palaeoproterozoic Mineralization Research Group (PPM), and the Department of Science and Technology (DST) and National Research Foundation (NRF) funded Centre of Excellence for Integrated Mineral and Energy Resource Analysis (CIMERA) for funding and support. AngloGold-Ashanti are thanked for access to their exploration drill core on which this study was conducted. The Geobiology journal thankfully granted permission for reuse of parts of figures from Smith et al. (2017) ${ }^{25}$. Many thanks go also to Dawn Sumner for providing literature.

\section{Author contributions}

A.J.B.S. acted as lead author and principle investigator. N.J.B. and J.G. had the original idea for the study, acted as post-graduate supervisor for A.J.B.S. when the study was started and contributed significantly to the text and figures. C.M.J. and A.D.C. acted as geochemistry consultants and contributed significantly to the text and figures. N.N. originally discovered the outcrop occurrence of the Nconga GIF in Swaziland. F.d.B. and J.W.H. conducted the $\mu \mathrm{XCT}$ scans, processed the data and made the 3D reconstructions at Necsa and authored parts of the methodology. S.M.A. consulted the lead author on stromatolite literature, terminology and morphology.

\section{Competing interests}

The authors declare no competing interests.

\section{Additional information}

Supplementary information is available for this paper at https://doi.org/10.1038/s41598-020-66805-0.

Correspondence and requests for materials should be addressed to A.J.B.S.

Reprints and permissions information is available at www.nature.com/reprints.

Publisher's note Springer Nature remains neutral with regard to jurisdictional claims in published maps and institutional affiliations.

(c) (i) Open Access This article is licensed under a Creative Commons Attribution 4.0 International

License, which permits use, sharing, adaptation, distribution and reproduction in any medium or format, as long as you give appropriate credit to the original author(s) and the source, provide a link to the Creative Commons license, and indicate if changes were made. The images or other third party material in this article are included in the article's Creative Commons license, unless indicated otherwise in a credit line to the material. If material is not included in the article's Creative Commons license and your intended use is not permitted by statutory regulation or exceeds the permitted use, you will need to obtain permission directly from the copyright holder. To view a copy of this license, visit http://creativecommons.org/licenses/by/4.0/.

(C) The Author(s) 2020 